\title{
An Application of Loop Mediated Iso-thermal Amplification Technology in Forensic Science
}

\author{
Brahmbhatt Nikunj ${ }^{1}$, Upasani Vivek ${ }^{2}$ \\ Research Scholar, Department of Biotechnology, Kadi Sarva Vishvavidayala, Gandhinagar, India ${ }^{1,}$ \\ Assoc. Professor, Dept. of Microbiology, M. G. Science Institute, Ahmedabad, India ${ }^{2}$ \\ Email: neelnikunj@yahoo.com ${ }^{1}$,vivekupasani@gmail.com ${ }^{2}$
}

\begin{abstract}
Cow (Bos indicus) is believed to be a sacred animal by Hindus and is protected by the law. It is therefore, a pivotal role of forensic scientists to develop a simple, sensitive, rapid and precise testing technique(s). In this study loop mediated isothermal amplification (LAMP) technique was developed and oligonucleotide primers were validated to detect cow meat (raw or cooked) in mixtures of beef with different concentrations of other animal meat. In this assay, no cross reactivity was found with other animal species, even the most closed inter-species buffalo did not show reactivity, and primer set was showed high specificity for cow only. The limits of detection (LODs) of the LAMP assays in raw and cooked meat were determined, which ranged from $100 \mathrm{ng} / \mu \mathrm{L}$ to $10 \mathrm{fg} / \mu \mathrm{L}$ levels, and LODs in raw and cooked meat admixtures were determined from $0.01 \%$ to $0.0001 \%$ levels. The assay was performed within 45 mins and showed higher sensitivity than that of the PCR assays. The outcome of the study stated that LAMP assay is a rapid, easy, consistent and sensitive method for forensic science application in detection of cow meat and its mixtures at the site of sampling or in laboratory. It would also be useful to solve judicial matters in criminal cases related to illegal cow slaughter an offence in India.
\end{abstract}

Index Terms- loop mediated isothermal amplification, PCR, cow meat, forensic science, primer validation.

\section{INTRODUCTION}

Technological innovations always help in improving analytical methods. In an attempt to curb illegal transportation of meat and slaughtering of protected animals, rapid and accurate method for analysis is necessary. In this study the loop mediated isothermal amplification was found to be an alternative and reliable technology for forensic science. It is often confusing to identify meat based on morphological characteristics, as meat of cow and buffalo without fat is difficult to identify. Law in India protects cow being sacred animal. Conventional detection for methods animal species identification many times fails to give conclusive results/reports. Hence, newer technologies are adopted to generate forensic report at the field or sampling site.

Generally methods for meat identification depend on protein analyses, such as immunological and electrophoretic assays (Bottero and Dalmasso, 2011). To overcome the problem with protein denaturation, many molecular biology based in vitro amplification of a nucleic acid sequence methods have been developed (Van Belkum A, 2003). These may allow rapid, sensitive and specific analysis comparable to conventional methods. The amplification methods, including polymerase chain reaction (PCR), strand displacement amplification (SDA) and nucleic acid sequence-based amplification (NASBA) are available in the market as kits as nucleic acid amplification tests (NATs) (Versalovic et al, 2002). NATs have been developed as an alternative to protein-based methods (Dooley et al., 2004; Koh et al., 2011; Wolf et al., 1999). Mitochondrial DNA (mtDNA) is relatively tolerant of environmental stresses, available in ample quantity in cell and its journey of evolution helps in discrimination between closely related species (Avise et al., 1987). mtDNA sequences like cytochrome $b$ and D-loop genes are exploited for identification of diverse species (Dooley et al., 2004; Santos et al., 2012; Wolf et al., 1999). Techniques using mtDNA targeting genes including random amplification of polymorphic DNA (RAPD) (Martinez et al, 1998), PCR - Restriction Fragment Length Polymorphism (Wolf et al., 1999), PCR (Koh et al, 2011), real-time PCR (Dooley et al., 2004; Santos et al., 2012) have been reported. But these technologies are found either less sensitive or laborious.

Originally, Loop-mediated isothermal amplification (LAMP) was reported in 1999 as mentioned by Natomi et al, (2000). LAMP has attracted a lot of attention as a potentially rapid, accurate, and costeffective novel nucleic acid amplification method. The binding of manganese ions quenches the fluorescence of calcein. Because the manganese ions are bound by pyrophosphate ions produced during amplification process, calcein produced bright fluorescence as positive reaction (Tomita et al, 2008). The LAMP reaction shows more robustness against inhibitors present in biological samples as compared to PCR; it saves time and sample processing steps (Kaneko et al, 2007). Designing of LAMP primes set is difficult, hence this technology is not widely accepted. But free software for designing LAMP primers is available for target sequence. Lamp employs DNA polymerases, such as Bst or Gsp DNA polymerase, and 4 to 6 specific primers, which are capable of inducing auto- 
International Journal of Research in Advent Technology, Vol.7, No.3, March 2019

\section{E-ISSN: 2321-9637 \\ Available online at www.ijrat.org}

cycling strand displacement. The reaction occurs under isothermal conditions, eliminating the need for thermal cycling.

In the present study, we used LAMP technology with a modification of the detection system for identification of origin of animal species from variety of meat and blood samples, especially in closed species like cow (Bos indicus) and buffalo (Bubalus arnee). The sensitivity, specificity, and applicability of this method for direct detection of cow species from samples were evaluated. Identification of species was ascertained on annealing curve analysis of the LAMP assays. The sensitivity of LAMP assay was assessed by measuring the limit of detection (LOD) for variety of samples tested like blood, raw meat, cooked meat, admixtures of blood samples and meat samples (Ae-Ri Cho et al, 2014). The LODs of LAMP assays were compared to those of PCR assays to evaluate the LAMP assays.

\section{MATERIALS AND METHODS}

\subsection{Samples Collection and Preparation}

In this study representative meat samples were collected from four animal species namely cow (Bos indicus), buffalo (Bubalus arnee), sheep (Ovis aries) and goat (Capra hircus) from veterinary health centers in the Gujarat state (India) and human viscera samples were also collected. Samples were preserved at $-20^{\circ} \mathrm{C}$ till used for DNA extraction. $50 \mathrm{mg}$ sample was e used for DNA extraction. Admixtures of meat were prepared by combining $0.5 \mathrm{gm}$ of cow meat at 0.0001 to $10 \%$ in $1.5 \mathrm{gm}$. of buffalo, sheep, goat and human meat, respectively. Each admixture was then homogenized by mincing for $5 \mathrm{~min}$. Each mixture was prepared in triplicate like raw mixture, roasted meat mixture (roasting for $5 \mathrm{mins}$ ), and third fried meat mixture by frying in edible oil for 5 mins.

\subsection{DNA Extraction and Quality Measurement}

Sample (20 mg / $50 \mathrm{mg}$ ) was used for DNA extraction QiaAmp Investigator Kit (Qiagen, USA) on QIACUBE DNA extraction platform (Qiagen, USA) following provider's guidelines. The extracted DNA was stored at $4^{\circ} \mathrm{C}$ in a refrigerator.

Horizontal submarine gel electrophoresis was performed to check the quality of extracted DNA using $0.8 \% \mathrm{w} / \mathrm{v}$ agarose gel. The extracted DNA was quantified using a Helma platform biospectrometer (Eppendorf, Germany) and the DNA samples with $\mathrm{OD}_{\text {260:280 }}$ ratio between 1.7 and 1.9 were considered good and used for PCR amplification.

\subsection{LAMP Primer Designing}

The oligonucleotide primers for the LAMP assay were selected from 12S rRNA and from cytochrome $b$ gene sequences of cow using GenBank, accession no. JN817330.1. The sequence was aligned using CLUSTALW in Meg Align Program of Lasergene software (DNASTAR Inc., USA) to develop a consensus sequence. A set of six oligonucleotide primers, including two outer primers (forward primer F3 and backward primer B3), two inner primers (forward inner primer FIP and backward inner primer BIP), and two loop primers (forward loop primer LoopF and backward loop primer LoopB) were designed using LAMP Designer software, ver. 1.10 (Optigene, UK).

\subsection{LAMP Reaction and Amplification Conditions}

LAMP reaction was performed in a total volume of 25 $\mu \mathrm{L}$ in a MicroAmp Fast 8-tube strip (Applied Biosystems, USA). Each reaction mixture containing $5 \mathrm{mM} \mathrm{F} 3$ and B3 primer $(25 \mathrm{pmol} / \mu \mathrm{L}), 20 \mathrm{mM}$ FIP and BIP primer $(25 \mathrm{pmol} / \mu \mathrm{l}), 10 \mathrm{mM}$ LoopF and LoopB primer $(25 \mathrm{pmol} / \mu \mathrm{l}), 3 \mathrm{mM} \mathrm{MgSO}_{2} \cdot 7 \mathrm{H}_{2} \mathrm{O}$ and $0.8 \mathrm{M}$ betaine and $5 \mu \mathrm{l}$ of isolated DNA template. The optimal reaction was evaluated at $65^{\circ} \mathrm{C}$ for $30 \mathrm{~min}$ with annealing curve analysis step (annealing at $98^{\circ} \mathrm{C}-$ $80^{\circ} \mathrm{C}$ ramping at $0.1^{\circ} \mathrm{C}$ per min) in a portable real-time isothermal amplification instrument (Genie III, OptiGene, UK). Initially primer set was tested for species specificity for cow. The best reaction temperature for the Bos (cow) species was determined as the point of earliest inflection in the amplification ratio curve. The results were represented with fluorescence $(\mathrm{K})$ on the $\mathrm{Y}$-axis and time $(\mathrm{T})$ on the $\mathrm{X}$ axis in the amplification graph. The selected set of primers showed successful amplification for cow meat in mixtures of cow-goat, cow-sheep, cow-buffalo and cow-human samples. Nucleotide-free distilled water was used as a negative control and cross-reactivity with non-target DNA samples was tested.

\subsection{Detection Limit of Assays}

Isolated template DNA from cow meat sample with additives of isolated DNA from buffalo sample (10\%, $1 \%, 0.1 \%, 0.01 \%$ and $0.001 \%)(\mathrm{w} / \mathrm{v})$ were tested in triplicates. The amplification rate and the analytical sensitivity of the LAMP assay was calculated on the basis of a dilution row. The analytic sensitivity of the LAMP assay for cow DNA was successfully measured. Whereas through conventional PCR, the reaction mixture contained $1 \times$ Master Mix, $0.5 \mu \mathrm{M}$ each primer, and $1 \mu \mathrm{L}$ template. The reaction was performed in a Thermal Cycler (Applied Biosystems, USA) with the following conditions; $95^{\circ} \mathrm{C}$ for $5 \mathrm{~min}$; followed by 30 cycles of $95^{\circ} \mathrm{C}$ for $30 \mathrm{~s}, 58^{\circ} \mathrm{C}$ for $30 \mathrm{~s}$ and $72^{\circ} \mathrm{C}$ for $30 \mathrm{~s}$ final extension, $72^{\circ} \mathrm{C}$ for $10 \mathrm{~min}$. Nucleotide-free distilled water was used as a negative control.

\section{RESULTS AND DISCUSSION}

\subsection{Specificity and Sensitivity of the LAMP Assay}

Five sets of primers were tested using $25 \mathrm{ng}$ of extracted DNA of cow under isothermal conditions ranging from $60^{\circ} \mathrm{C}$ to $70^{\circ} \mathrm{C}$ for 45 mins. Two primer sets among five showed positive results, but intensity and specificity was satisfied by primer set 3 . The specificity of LAMP assay was checked by amplifying the DNA samples of cow, buffalo, goat, sheep and human. No significant amplification was detected in the samples of the tested species except for that of cow 


\section{Available online at $w w w . i j r a t . o r g$}

meat sample using both PCR and LAMP assays. The optimal reaction temperatures for each LAMP assay were identified as $65^{\circ} \mathrm{C}$. As no cross reactivity was observed when the single plex LAMP assays were performed for each of the mixture groups of meat samples, indicating that the selected markers are suitable for species discrimination.

\subsection{Detection Limits of LAMP Assay}

The amplification rate and the analytical sensitivity of the LAMP assay was calculated based on a dilution row (Figure 1), the amount of the DNA isolated was ranging from $100 \mathrm{ng} / \mu \mathrm{l}$ to $100 \mathrm{fg} / \mu \mathrm{l}$ from cow sample (Figure 2). The analytic sensitivity of the LAMP assay for cow DNA was successfully measured up to 10 $\mathrm{fg} / \mu \mathrm{l}$ reaction, yielding a detection probability of $100 \%$ (all triplicate LAMP reactions were positive). This concentration could be detected by a detection time of approximately 18:14 ( \pm 0.7$)$ minutes. The LAMP assay showed no fluorogenic signal for the negative control as well as the non-cow sample (Figure 3). Furthermore, no significant differences among the different forms of cow samples like raw meat, cooked meat were observed. The melting temperature observed for the specific cow amplicon at was $85.7^{\circ} \mathrm{C}\left( \pm 0.5^{\circ} \mathrm{C}\right)$ (Figure 4$)$. Previously reported primers and conditions were used for the PCR-based comparators (Brahmbhatt et al, 2019) with minor modifications. All triplicate LAMP reactions carried out by PCR were showing consistent results.

The limits of PCR and LAMP assay in fresh blood and serially diluted blood samples along with raw and cooked meat samples were measured and shown in (Table 1 and Table 2). Amplification curves, for blood sample assay was generated in the range of 125 $\mathrm{ng} / \mu \mathrm{L}$ to $10 \mathrm{fg} / \mu \mathrm{L}$, and for meat samples in the range of $100 \mathrm{ng} / \mu \mathrm{L}$ to $10 \mathrm{fg} / \mu \mathrm{L}$. The LAMP assay was found more sensitive $\left(10^{2}\right.$ to $10^{3}$ times $)$ as compared to PCR. TaqMan-based real-time PCR studies of raw cattle meat samples yielded 35 pg DNA as reported by Zhang et al. (2007). The detection time does not change for raw meat or cooked meat. The reason is, targeted fragment of less than $150 \mathrm{bp}$ does not get influenced by heat treatment (Kesmen et al, 2012). This demonstrates the robustness of LAMP in the presence of PCR inhibitor substances like salt, spices and cooking oil. The rapid amplification time and its low susceptibility to inhibition factors are significant properties for the application suitability of this assay in the investigation of food samples. Thus, this method can be used for degraded sample as well as cooked meat if the DNA is successfully extracted. In this LAMP assay the negative control as well as the meat (without cow meat) yielded no fluorogenic signal.

Until now, species identification in meat samples is based on immunological, PCR-RFLP analysis, species-specific conventional PCR or Real-time PCR (Abdulmawjood et al, 2003). LAMP is the method appeared to be an alternative to the PCR-based methods, not only in food safety testing but also in other application fields of forensic assays. To our knowledge, this is the first report on the use of the LAMP assay for the species identification of meat products, for forensic purpose.

\section{FIGURES}




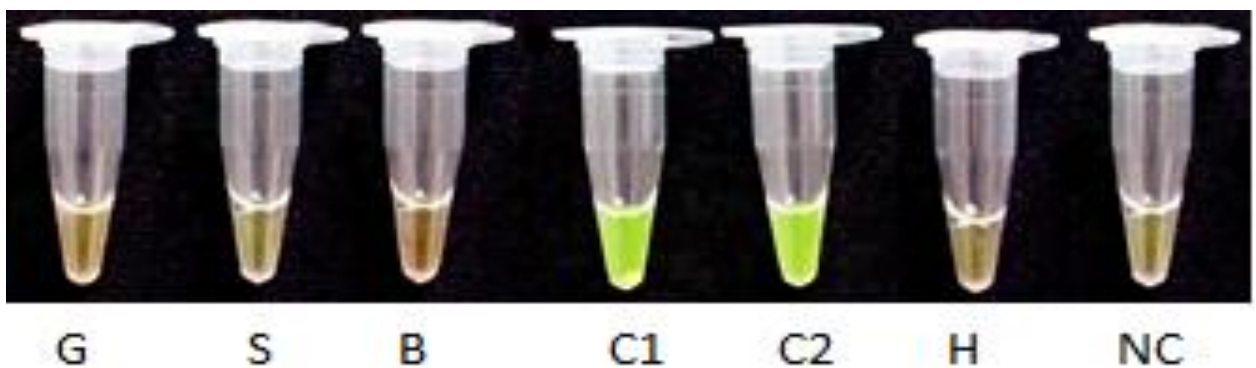

Fig. 1. Specificity reaction of primer set no: 3 with different animal meat samples, where G is goat, $\mathrm{S}$ is Sheep, $\mathrm{B}$ is Buffalo, $\mathrm{C} 1$ and $\mathrm{C} 2$ are Cow, $\mathrm{H}$ is Human and $\mathrm{NC}$ is Negative control.

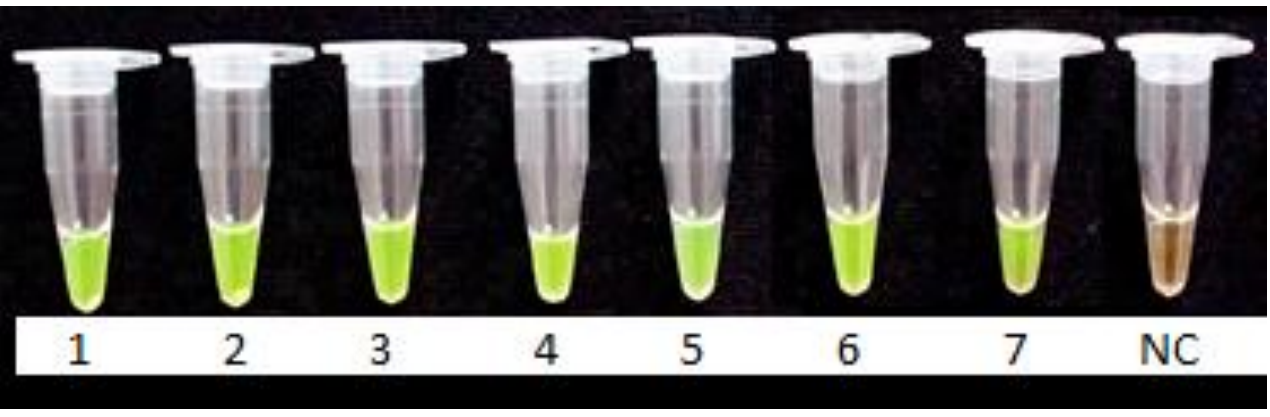

Fig. 2. Limit of detection of LAMP assay. Tubes 1-7: 10-fold dilutions of purified DNA with concentrations ranging from $100 \mathrm{ng}$ to $100 \mathrm{fg}$ per microliter (tubes 1 to 7 in order) were tested.

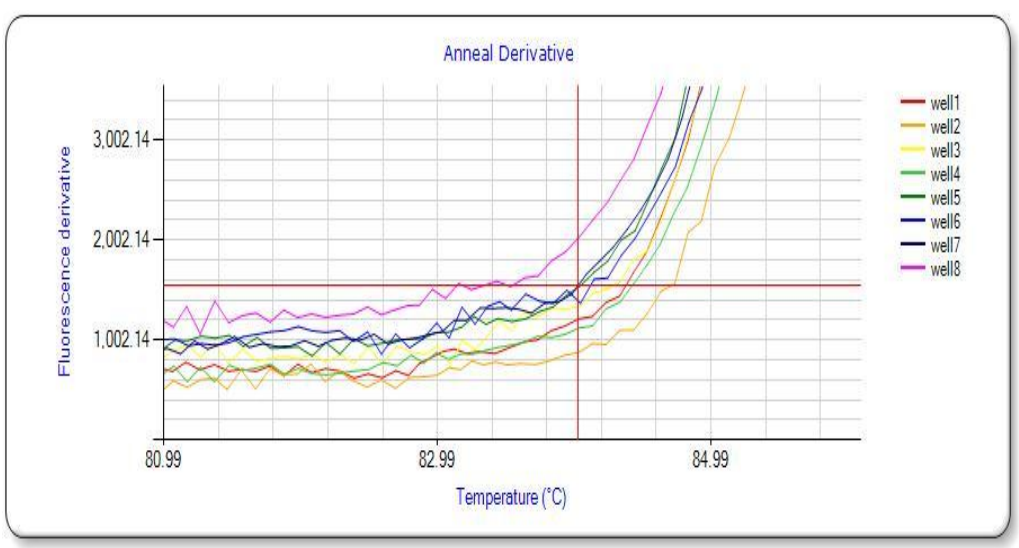

Fig. 3. Amplification curve for cooked meat sample of cow.

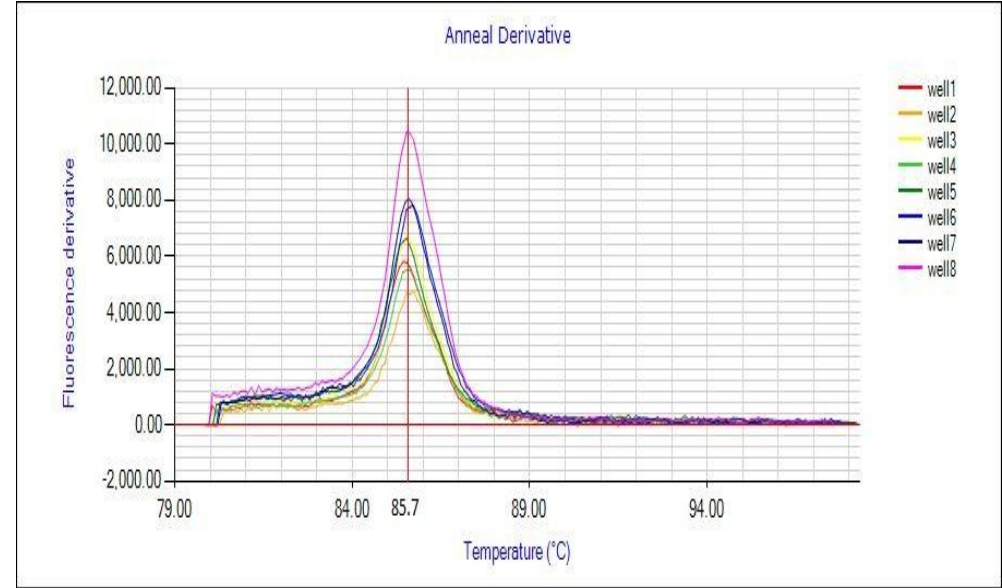

Fig. 4. Annealing curve analysis of cooked meat samples of cow. 
International Journal of Research in Advent Technology, Vol.7, No.3, March 2019

E-ISSN: 2321-9637

Available online at www.ijrat.org

\section{TABLES}

Table: 1: Sensitivity Assays with blood samples

\begin{tabular}{|l|l|l|l|l|l|}
\hline \multicolumn{2}{|l|}{ Fresh Blood } & \multicolumn{2}{l|}{ Cow : Buffalo Admixture } \\
\hline $\begin{array}{l}\text { Concentration } \\
\text { of DNA Template }\end{array}$ & $\begin{array}{l}\text { Detection Time } \\
\text { by LAMP } \\
\text { (minute) }\end{array}$ & PCR & $\begin{array}{l}\text { Concentration } \\
\text { of blood (\%) }\end{array}$ & $\begin{array}{l}\text { Detection Time } \\
\text { by LAMP } \\
\text { (minute) }\end{array}$ & PCR \\
\hline $125 \mathrm{ng}$ & $17.4 \pm 0.5$ & + & 10 & $12.8 \pm 0.3$ & + \\
\hline $12.5 \mathrm{ng}$ & $18.5 \pm 0.3$ & + & 1 & $13.8 \pm 0.4$ & + \\
\hline $1.25 \mathrm{ng}$ & $20.2 \pm 0.4$ & + & 0.1 & $15.2 \pm 0.5$ & \\
\hline $125 \mathrm{pg}$ & $23.3 \pm 0.5$ & + & 0.01 & $17.5 \pm 0.7$ & \\
\hline $12.5 \mathrm{pg}$ & $25.6 \pm 0.3$ & & 0.001 & & \\
\hline $1.25 \mathrm{pg}$ & $27.2 \pm 0.2$ & & 0.0001 & & \\
\hline $125 \mathrm{fg}$ & $29.5 \pm 0.3$ & & 0.00001 & & \\
\hline $12.5 \mathrm{fg}$ & & & & & 0.9255 \\
\hline $\mathrm{R}^{2}$ & 0.9930 & & & $85.6 \pm 0.3$ & \\
\hline $\mathrm{T}_{(\mathrm{m})}\left({ }^{\circ} \mathrm{C}\right)$ & $85.7 \pm 0.5$ & & & & \\
\hline
\end{tabular}

Note: The admixture of cow-buffalo blood was prepared by mixing $2 \mathrm{~mL}$ of buffalo blood at $10 \%$ to $0.00001 \%$ in $1.0 \mathrm{~mL}$ of cow blood

Table: 2: Sensitivity Assays with meat samples.

\begin{tabular}{|l|l|l|l|l|}
\hline \multicolumn{2}{|l|}{ Raw Meat } & Cooked Meat \\
\hline $\begin{array}{l}\text { Concentration of } \\
\text { DNA Template }\end{array}$ & $\begin{array}{l}\text { Detection Time } \\
\text { by LAMP } \\
\text { (minute) }\end{array}$ & PCR & $\begin{array}{l}\text { Detection Time } \\
\text { by LAMP } \\
\text { (minute) }\end{array}$ & PCR \\
\hline $100 \mathrm{ng}$ & $18.2 \pm 0.3$ & + & $15.8 \pm 0.3$ & + \\
\hline $10 \mathrm{ng}$ & $18.7 \pm 0.3$ & + & $17.5 \pm 0.4$ & + \\
\hline $1 \mathrm{ng}$ & $21.2 \pm 0.4$ & + & $18.4 \pm 0.5$ & \\
\hline $100 \mathrm{pg}$ & $22.4 \pm 0.4$ & + & $20.8 \pm 0.3$ & \\
\hline $10 \mathrm{pg}$ & $23.6 \pm 0.3$ & + & $22.6 \pm 0.4$ & \\
\hline $1 \mathrm{pg}$ & $27.2 \pm 0.2$ & & $25.4 \pm 0.5$ & \\
\hline $100 \mathrm{fg}$ & $29.5 \pm 0.3$ & & $27.2 \pm 0.3$ & \\
\hline $10 \mathrm{fg}$ & & & & \\
\hline $\mathrm{R}^{2}$ & 0.9930 & & 0.9935 & \\
\hline $\mathrm{T}_{(\mathrm{m})}\left({ }^{\circ} \mathrm{C}\right)$ & $85.47 \pm 0.4$ & & $85.7 \pm 0.3$ & \\
\hline
\end{tabular}

Note: Limits of the LAMP assay and detection time of raw meat and cooked meat of cow

\section{Acknowledgments}

We wish to thank the authorities and scientists of Directorate of Forensic Science, Gujarat, India for providing laboratory facilities.

We also express our gratitude to Deputy Director of Animal Husbandry, FMD Typing Scheme, Ahmedabad, India for their assistance in collection of required control reference samples.

We are grateful to Dr. Deepal Pandya, Director, AmpliGene India Pvt. Ltd., Ahmedabad, India for providing technology and lab facility for research analysis.

\section{REFERENCES}

[1] Abdulmawjood A., Scho“nenbru“cher H., Bu“lte M. (2003) Development of a polymerase chain reaction system for the detection of $\operatorname{dog}$ and cat meat in meat mixtures and animal feed. J Food Sci 68: 1757-1761.

[2] Ae-Ri Cho., Hee-Jin Dong, and Seongbeom Cho. (2014): Meat Species Identification using Loopmediated Isothermal Amplification Assay Targeting Species-specific Mitochondrial DNA. Korean J. Food Sci. An. 34(6), 799-807.

[3] Avise, J. C., Arnold, J., Ball, R. M., Bermingham, E., Lamb, T., Neigel, J. E., Reeb, C. A., and Saunders, N. C. (1987) Intraspecific phylogeography the mitochondrial DNA bridge 


\section{Available online at $w w w . i j r a t . o r g$}

between population-genetics and systematics. Annu. Rev. Ecol. Syst. 18, 489-522.

[4] Bottero, M. T. and Dalmasso, A. (2011) Animal species identification in food products: evolution of biomolecular methods. Vet. J. 190, 34-38.

[5] Brahmbhatt N., Pandya D., Brahmbhatt D., Vyas J., Upasani V. (2019): An application of Loopmediated Isothermal Amplification Assay for Identification of Closely Related Species in Cattle, Journal of Emerging Technologies and Innovative Research, 6(1), 445-453.

[6] Dooley, J. J., Paine, K. E., Garrett, S. D., and Brown, H. M. (2004) Detection of meat species using TaqMan real-time PCR assays. Meat Sci. 68, 431-438.

[7] Kaneko H, Kawana T, Fukushima E, Suzutani T. (2007) Tolerance of loop-mediated isothermal amplification to a culture medium and biological substances. J Biochem Biophys Methods;70:499501.

[8] Kesmen, Z., Yetiman, A. E., Sahin, F., and Yetim, H. (2012) Detection of chicken and turkey meat in meat mixtures by using real-time PCR assays. J. Food Sci. 77, C167-173.

[9] Koh, B. R. D., Kim, J. Y., Na, H. M., Park, S. D., and Kim, Y. H. (2011) Development of speciesspecific multiplex PCR assays of mitochondrial $12 \mathrm{~S}$ rRNA and 16S rRNA for the identification of animal species. Korean J. Vet. Serv. 34, 417-428.

[10] Mane, B.G., Tanwar, V.K., Girish, P.S. and Dixit, V.P. (2006) 'Identification of species origin of meat by RAPD-PCR technique', Journal of Veterinary Public Health, 4, 7-90.

[11] Martinez, I. and Malmheden Yman, I. (1998) Species identification in meat products by RAPD analysis. Food Res. Int. 31, 459-466.

[12] Notomi T., Okayama H., Masubuchi H., Yonekawa T., Watanabe K., Amino N., Hase T. (2000) Loop-mediated isothermal amplification of DNA. Nucleic Acids Res 28:E63.

[13] Santos, C. G., Melo, V. S., Amaral, J. S., Estevinho, L., Oliveira, M. B., and Mafra, I. (2012) Identification of hare meat by a speciesspecific marker of mitochondrial origin. Meat Sci. 90, 836-841.

[14] Tomita N., Mori Y., Kanda H., Notomi T. (2008) Loop-mediated isother-mal amplification (LAMP) of gene sequences and simple visual detection of products. Nat Protoc;3:877-82.

[15] van Belkum A.(2003) Molecular diagnostics in medical microbiology: yesterday, today and tomorrow. Curr Opin Pharmacol;3: 497-501.

[16] Versalovic J., Lupski JR. (2002) Molecular detection and genotyping of pathogens: more accurate and rapid answers. Trends Microbiol; 10:S15-21.

[17] Wolf, C., Rentsch, J., and Hübner, P. (1999) PCR-RFLP analysis of mitochondrial DNA: a reliable method for species identification. J. Agr. Food Chem. 47, 1350-1355.
[18]Zhang, C. L., Fowler, M. R., Scott, N. W., Lawson, G., and Slater, A. (2007) A TaqMan real-time PCR system for the identification and quantification of bovine DNA in meats, milks and cheeses. Food Control 18, 1149-1158. 